\title{
Qiliqiangxin improves oxidized low-density lipoprotein-induced human coronary artery endothelial cells injury.
}

\author{
Changjiang Du ${ }^{1 \#}$, Haiqin $\mathrm{Lv}^{2 \#}$, Guangyuan Meng ${ }^{3}$, Xiujuan Wang 4 , Haijun Cao ${ }^{\text {* }}$ \\ ${ }^{1}$ Department of Cardiovascular Surgery, the Central Hospital of Tai' an, 29 Long Tan Road, Tai' an, PR China \\ ${ }^{2}$ Department of Pharmacy, the Affiliated Hospital of Taishan Medical University, Taishan Street, Tai'an, PR China \\ ${ }^{3}$ The Central Hospital of Tai'an, 29 Long Tan Road, Tai'an, PR China \\ ${ }^{4}$ The Information Engineering Institute of Taishan Medical University, 619 Chang Cheng Road, Tai' an, PR China \\ ${ }^{5}$ Department of Anesthesia, the Central Hospital of Tai'an, 29 Long Tan Road, Tai'an, PR China \\ \#These authors contributed equally to this work
}

\begin{abstract}
Qiliqiangxin (QL) has protective effect for the cardiovascular diseases treatment. This study aim to evaluate the effect of $Q L$ on the cell viability, cell apoptosis and caspase-3 activity in oxidized LDL (oxLDL)-induced Human Coronary Artery Endothelial Cells (HCAECs). HCAECs were treated with QL $(0-1 \mu \mathrm{g} / \mathrm{ml})$ and oxLDL $(150 \mu \mathrm{g} / \mathrm{ml})$. The HCAECs viability was detected by cell proliferation assay and Lactate Dehydrogenase (LDH) release assay. The HCAECs apoptosis was evaluated by the annexin V-FITC assay. The activity of caspase-3 of HCAECs was measured by colorimetric caspase-3 assay. Cell migration assay and capillary-like tube formation assay on Matrigel were performed. Treatment of HCAECs to ox-LDL $(150 \mu \mathrm{g} / \mathrm{ml})$ decreased cell viability, stimulated apoptosis and enhanced caspase-3 activity. In addition, treatment with $\mathrm{QL}(0.5 \mu \mathrm{g} / \mathrm{ml})$ alone did not affect cell viability and $\mathrm{LDH}$ release. Furthermore, the treatment with QL $(0.5 \mu \mathrm{g} / \mathrm{ml})$ significantly increased ox-LDL $(150 \mu \mathrm{g} / \mathrm{ml})$ decreased cell viability. Treatment with QL $(0.5 \mu \mathrm{g} / \mathrm{ml})$ reduced ox-LDL-stimulated apoptosis and caspase-3 activity in HCAECs in a dose-dependent manner. QL $(0.5 \mu \mathrm{g} / \mathrm{ml})$ attenuated ox-LDL $(150 \mu \mathrm{g} / \mathrm{ml})$ abolished cell migration and tube formation. Our study demonstrated that QL prevents ox-LDLinduced HCAECs injury by decreasing the apoptosis via caspase-3 activity.
\end{abstract}

Keywords: Qiliqiangxin, Oxidized LDL, Apoptosis, Human microvascular endothelial cells, Caspase-3. Accepted on November 22, 2017

\section{Introduction}

Dysfunction of vascular Endothelial Cells (ECs) has regarded as a high risk factor for the Atherosclerosis (AS) development $[1,2]$. It has also been demonstrated that ECs apoptosis induced atherosclerotic lesion development and plaque shedding [3-5]. Oxidized Low-Density Lipoprotein (ox-LDL), an important atherosclerotic risk factor, may induce ECs apoptosis during the pathogenesis of AS [6-8]. Hence, inhibition of ox-LDL induced ECs apoptosis may suggest new therapies in the AS treatment.

Qiliqiangxin (QLQX) is a traditional Chinese herbs medication, which are extracted from 11 distinct herbs including Radix Astragali, Ginseng, Salvia miltiorrhiza, Cortex Periplocae Sepii Radicis, Rhizoma Alismatis, Seasoned Orange Peel, Aconite Root, Carthamus tinctorius, Semen Lepidii Apetali, Polygonatum Odorati, and Rumulus Ginnamomi. Recent work has presented that QL is an effective agent in the cardiovascular diseases treatment $[9,10]$. QL showed the protective effects in the cardiovascular system via reducing myocardial apoptosis and cardiac fibrosis, thus protecting cardiac function. Moreover, QL Recently, another study reported that chronic administration of QL improved inflammation respond and improved energy metabolism progress. Although the protective regulation of QL on injured cells has achieved significant advance, the effect of QL on injury ECs is still largely elusive.

The excessive caspase- 3 activity induced cell apoptosis in various types of cells [11-13]. Ox-LDL induced cells apoptosis via eliciting the caspase-3 activity [14-18]. However, the protective effect of QL to the ox-LDL induced ECs injury remains unknown. In the present study, we used Human Coronary Artery Endothelial Cells (HCAECs) to investigate the protective effects of QL on ox-LDL induced cell injury. 


\section{Methods}

\section{Materials}

QL, provided by Shijiazhuang Yiling Pharmaceutical Co. Ltd (Shijiazhuang, Hebei, China), was diluted in culture media to various concentrations $(0.25,0.5$, and $1.0 \mu \mathrm{g} / \mathrm{ml})$. Recombinant human oxidized LDL was obtained from BioSun (Shanghai BioSun, Shanghai, China). Cell Counting Kit 8 (CCK-8, CK04) was obtained from Dojindo Laboratories (Kumamoto, Japan). Lactic acid dehydrogenase (LDH) assay kit was purchased from Bio Vision (CA, USA).

\section{Cell culture and treatment}

HCAECs were obtained from the American Type Culture Collection (ATCC) (Lot ${ }^{\#} 61492256$, Manassas, VA, USA). Cells were seeded in endothelial cell growth medium supplemented with $10 \%$ fetal bovine serum and $100 \mathrm{U} / \mathrm{ml}$ penicillin-streptomycin solution at $37^{\circ} \mathrm{C}, 5 \% \quad \mathrm{CO}_{2}$ in an incubator. For the treatment, HCAECs were treated with QL $(0-1 \mu \mathrm{g} / \mathrm{ml})$ and ox-LDL $(150 \mu \mathrm{g} / \mathrm{ml})$ for $24 \mathrm{~h}$.

\section{Cell viability assay}

The cell viability was performed by Cell Counting Kit- 8 (CCK-8) kit (Dojindo, Kumamoto, Japan) according to the manufacturer's protocol [19]. HCAECs $\left(5 \times 10^{4} /\right.$ well $)$ were incubated in 96-well plates with QL $(0-1 \mu \mathrm{g} / \mathrm{ml})$ and ox-LDL $(150 \mu \mathrm{g} / \mathrm{ml})$ for $24 \mathrm{~h}$, then CCK- $8(10 \mu \mathrm{L})$ reagent was added for $2 \mathrm{~h}$ at $37^{\circ} \mathrm{C}$. The plates were detected at $450 \mathrm{~nm}$ by a microplate reader (Bio-Rad technology, CA, USA).

\section{LDH release assay}

HCAECs $\left(5 \times 10^{4} /\right.$ well $)$ were cultured in 96-well plates with QL $(0-1 \mu \mathrm{g} / \mathrm{ml})$ and ox-LDL $(150 \mu \mathrm{g} / \mathrm{ml})$ for $24 \mathrm{~h}$. The LDH released into the cell media were used to detect LDH activity using an analysis kit according to the manufacturer's instructions.

\section{Flow cytometry}

The percentage of apoptotic cells was calculated by annexin VFITC and Propidium Iodide (PI) kit according to the manufacturer's protocol. In brief, HCAECs $\left(2 \times 10^{5} /\right.$ well $)$ were cultured in 6-well plates with QL $(0-1 \mu \mathrm{g} / \mathrm{ml})$ and ox-LDL $(150 \mu \mathrm{g} / \mathrm{ml})$ for $24 \mathrm{~h}$. Then cells were harvested and incubated annexin V-FITC and PI with for $15 \mathrm{~min}$ at room temperature in the dark. The cell apoptotic rates were then quantified by flow cytometry.

\section{Measurement of caspase-3 activity}

The activity of caspase- 3 was detected by a colorimetric caspase-3 assay kit (Sigma, St. Louis, MO, USA) according to the manufacturer's protocol [20]. HCAECs $\left(2 \times 10^{5} /\right.$ well $)$ were cultured in 6-well plates with QL $(0-1 \mu \mathrm{g} / \mathrm{ml})$ and ox-LDL $(150 \mu \mathrm{g} / \mathrm{ml})$ for $24 \mathrm{~h}$. The cell lysate were added with caspase- 3 substrate at $37^{\circ} \mathrm{C}$ for $90 \mathrm{~min}$. The plates were detected at $405 \mathrm{~nm}$ by a microplate reader (Bio-Rad technology, CA, USA).

\section{Cell migration assay}

Cell migration assay were presented in 24-well Transwell plates with $8 \mu \mathrm{m}$ pores (Corning, Santa Clara, CA, USA). HCAECs $\left(5 \times 10^{5}\right)$ were cultured in the upper culture chambers, while basic medium with $10 \%$ FBS was added to the lower chambers for $6 \mathrm{~h}$. The migrated cells were counted and assessed. Filters were stained with Calcein AM $(2 \mu \mathrm{g} / \mathrm{ml})$ for $15 \mathrm{~min}$. Three random fields were counted by a Nikon Eclipse TS100 microscope (Nikon, Tokyo, Japan).

\section{Tube forming assay}

The tube formation was assessed by precoated Matrigel 24well culture plates, as previously described [19]. Matrigel (BD Bioscience, San Jose, CA, USA) was added to each well of the 96-well culture plates at $37^{\circ} \mathrm{C}$ for $1 \mathrm{~h}$ for polymerization. The cells were added to the Matrigel-coated wells and incubated at $37^{\circ} \mathrm{C}$ in $5 \% \quad \mathrm{CO}_{2}$ atmosphere. The tube formation was photographed by a Nikon Eclipse TS100 microscope (Nikon, Tokyo, Japan).

\section{Statistical analysis}

Differences between treatments were assessed by one-way ANOVA followed by a Tukey test (Bartlett test $\mathrm{p}>0.05$ ) to compare mean of treatments with controls. Results are given as mean \pm standard error of mean.

\section{Results}

\section{$Q L$ increases cell viability in ox-LDL-exposed HCAECS}

Firstly, we detected the cytotoxicity of QL on HCAECs. Our data showed that QL $(1 \mu \mathrm{g} / \mathrm{ml})$ treatment did not affect HCAECs cell viability for $24 \mathrm{~h}(\mathrm{p}>0.05$ vs. control) (Figure 1a). Additionally, ox-LDL $(150 \mu \mathrm{g} / \mathrm{ml})$ treatment decreased cell viability for $24 \mathrm{~h}$ (Figure $1 \mathrm{~b}$ ). Further, our data showed that QL suppresses ox-LDL reduced the HCAECs viability in a dose dependent manner (Figure 1c).

\section{$Q L$ inhibits $L D H$ release in ox- $L D L$-exposed HCAECS}

The LDH release were used to assess whether QL affect oxLDL-induced HCAECs injuries. As shown in Figure 2a, QL (1 $\mu \mathrm{g} / \mathrm{ml})$ did not affect the LDH release in HCAECs. Moreover, ox-LDL $(150 \mu \mathrm{g} / \mathrm{ml})$ treatment elevated $\mathrm{LDH}$ release in HCAECs, compared with control group $(\mathrm{P}<0.05)$ (Figure $2 b$ ). Treatment with QL $(1 \mu \mathrm{g} / \mathrm{ml})$ reduced ox-LDL induced the $\mathrm{LDH}$ release in a dose dependent manner (Figure 2c).

\section{QL inhibits ox-LDL-induced apoptosis in HCAECs}

To analyse the anti-apoptotic effects of QL on ox- LDL-treated HCAECs, annexin V-PI and flow cytometry assay were 
performed. QL $(1 \mu \mathrm{g} / \mathrm{ml})$ did not affect the apoptosis in HCAECs (Figure 3a).

As seen in Figure 3b, ox-LDL increased HCAECs apoptosis compared with control $(\mathrm{P}<0.01)$. Treatment with $\mathrm{QL}(1 \mu \mathrm{g} / \mathrm{ml})$ reduced ox-LDL increased HCAECs apoptosis in a dose dependent manner (Figure 3c).



Figure 1. $Q L$ increases cell viability in ox-LDL-exposed HCAECs. Cell viability was evaluated by CCK-8 assay. (A) HCAECs were incubated with $Q L(1 \mu \mathrm{g} / \mathrm{ml})$ for $24 \mathrm{~h}$. (B) HUVECs were incubated with ox-LDL $(150 \mu \mathrm{g} / \mathrm{ml})$ for $24 \mathrm{~h}$. (C) HCAECs were incubated with $Q L(1 \mu \mathrm{g} / \mathrm{ml})$ and ox- $L D L(150 \mu \mathrm{g} / \mathrm{ml})$ for $24 \mathrm{~h}$. Data are presented as means $\pm S E M$ of 3 independent experiments. ${ }^{*}<0.05$ vs. control group. ${ }^{* *} p<0.01$ vs. control group. ${ }^{\#} P<0.05$, compared to the oxLDL group.



Figure 2. $Q L$ inhibits $L D H$ release in ox- $L D L$-exposed HCAECs. (A) HCAECs were incubated with QL $(1 \mu \mathrm{g} / \mathrm{ml})$ for $24 \mathrm{~h}$. (B) HUVECs were incubated with ox-LDL $(150 \mu \mathrm{g} / \mathrm{ml})$ for $24 \mathrm{~h}$. (C) HCAECs were incubated with $Q L(1 \mu \mathrm{g} / \mathrm{ml})$ and $\mathrm{ox}-L D L(150 \mu \mathrm{g} / \mathrm{ml})$ for $24 \mathrm{~h}$. Data are presented as means \pm SEM of 3 independent experiments. ${ }^{*} p<0.05$ vs. control group. ${ }^{* *} p<0.01$ vs. control group. ${ }^{\#} P<0.05$, compared to the oxLDL group.

\section{$Q L$ inhibits ox-LDL-induced caspase-3 activity in HCAECS}

Subsequently, we detected the effect of QL on ox-LDLinduced caspase-3 activity in HCAECs. QL $(1 \mu \mathrm{g} / \mathrm{ml})$ did not affect the caspase- 3 activity in HCAECs (Figure 4a). The oxLDL treatment enhanced the caspase-3 activity $(\mathrm{P}<0.01)$ (Figure 4b). Moreover, treatment of HCAECs with QL (1 $\mu \mathrm{g} / \mathrm{ml})$ inhibited ox-LDL stimulates caspase-3 activation (Figure 4c), implied that HCAECs may undergo caspase independent apoptosis signal pathway when treated with QL (1 $\mu \mathrm{g} / \mathrm{ml})$ and ox-LDL.

\section{QL promoted migration in ox-LDL treated HCAECS}

To detect the protective effects of QL on ox-LDL-treated HCAECs, Transwell migration assay were performed. As seen in Figure 5, ox-LDL increased HCAECs apoptosis compared with control $(\mathrm{P}<0.01)$. Treatment with $\mathrm{QL}(1 \mu \mathrm{g} / \mathrm{ml})$ reversed ox-LDL reduced HCAECs migration.

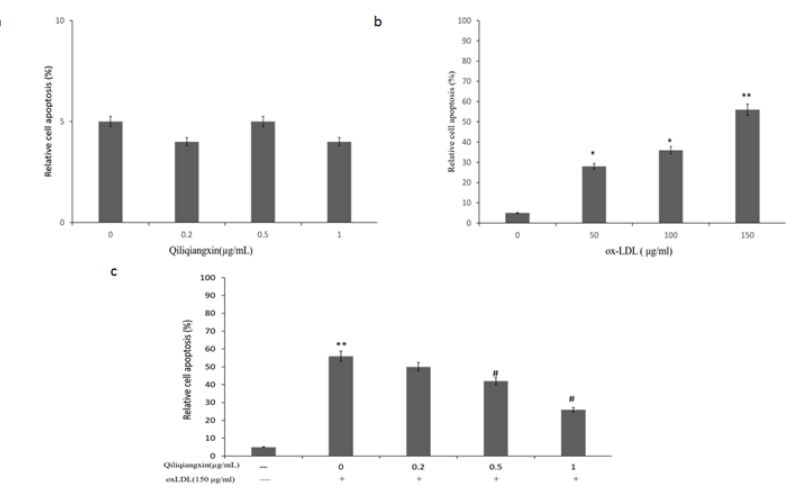

Figure 3. $Q L$ inhibits cell apoptosis in ox-LDL-exposed HCAECs. (A) HCAECs were incubated with QL $(1 \mu \mathrm{g} / \mathrm{ml})$ for $24 \mathrm{~h}$. (B) HUVECs were incubated with ox-LDL $(150 \mu \mathrm{g} / \mathrm{ml})$ for $24 \mathrm{~h}$. (C) HCAECs were incubated with $Q L(1 \mu \mathrm{g} / \mathrm{ml})$ and $o x-L D L(150 \mu \mathrm{g} / \mathrm{ml})$ for $24 \mathrm{~h}$. Data are presented as means $\pm S E M$ of 3 independent experiments. ${ }^{*} p<0.05$ vs. control group. ${ }^{* *} p<0.01$ vs. control group. ${ }^{\#} P<0.05$, compared to the oxLDL group.

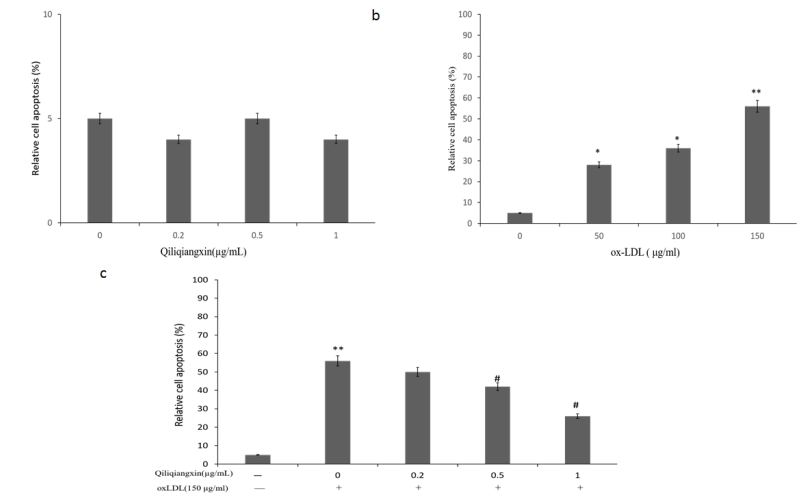

Figure 4. $Q L$ inhibits caspase-3 activity in ox-LDL-exposed HCAECs. (A) HCAECs were incubated with $Q L$ (1 $\mu \mathrm{g} / \mathrm{ml})$ for $24 \mathrm{~h}$. (B) HUVECs were incubated with ox-LDL (150 $\mu \mathrm{g} / \mathrm{ml})$ for $24 \mathrm{~h}$. (C) HCAECs were incubated with $Q L(1 \mu \mathrm{g} / \mathrm{ml})$ and $\mathrm{ox}-L D L(150 \mu \mathrm{g} / \mathrm{ml})$ for $24 \mathrm{~h}$. Data are presented as means \pm SEM of 3 independent experiments. ${ }^{*} p<0.05$ vs. control group. ${ }^{* *} p<0.01$ vs. control group. ${ }^{\#} P<0.05$, compared to the ox-LDL group.

\section{$Q L$ promoted tube formation in ox- $L D L$ treated HCAECS}

To detect the protective effects of QL on ox- LDL-treated HCAECs, tube formation assay were performed. As seen in Figure 6, ox-LDL reduced HCAECs tube formation compared with control $(\mathrm{P}<0.01)$. Treatment with $\mathrm{QL}(1 \mu \mathrm{g} / \mathrm{ml})$ reversed ox-LDL reduced HCAECs tube formation. 




Figure 5. QL promoted migration in ox-LDL treated HCAECs. HCAECs were incubated with $Q L(1 \mu \mathrm{g} / \mathrm{ml})$ and ox- $L D L(150 \mu \mathrm{g} / \mathrm{ml})$ for $24 \mathrm{~h}$. Data are presented as means \pm SEM of 3 independent experiments. ${ }^{*} p<0.05$ vs. control group. ${ }^{* *} p<0.01$ vs. control group. ${ }^{\#} P<0.05$, compared to the oxLDL group. Scale bar represents $10 \mu \mathrm{m}$.
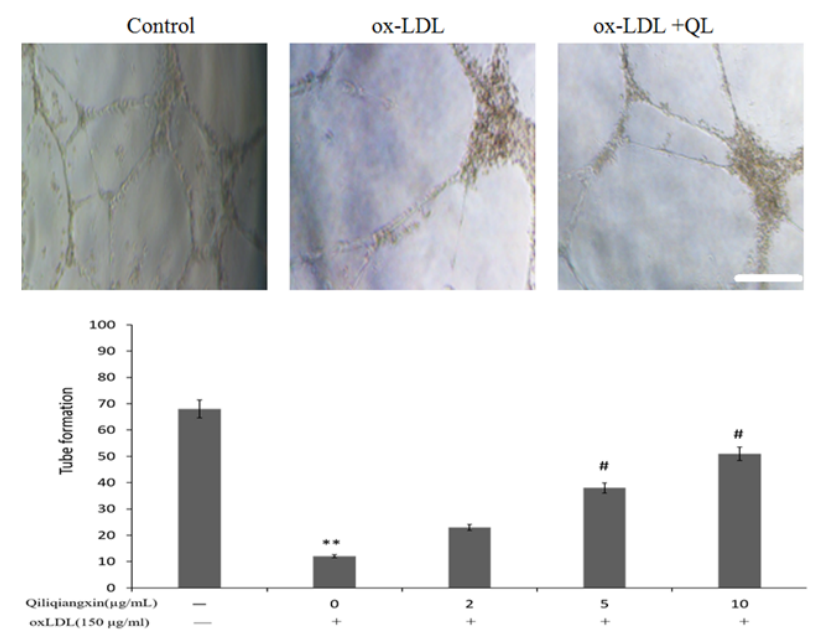

Figure 6. $Q L$ promoted tube formation in ox-LDL treated HCAECs. HCAECs were incubated with $Q L(1 \mu \mathrm{g} / \mathrm{ml})$ and $\mathrm{ox}-\mathrm{LDL}(150 \mu \mathrm{g} / \mathrm{ml})$ for $24 \mathrm{~h}$. Data are presented as means \pm SEM of 3 independent experiments. ${ }^{*} p<0.05$ vs. control group. ${ }^{* *} p<0.01$ vs. control group. ${ }^{\#} P<0.05$, compared to the ox-LDL group. Scale bar represents 100 $\mu m$.

\section{Discussion}

The endothelial cells dysfunction is a key event in the atherosclerosis progress development. It is also well-known that ECs apoptosis induces atherosclerotic plaques and thrombosis formation, which could cause coronary artery disease [21]. Exposure to ox-LDL induced endothelial cells apoptosis. Considering the key role of ox-LDL in the atherosclerosis progression development, we used ox-LDLtreated HCAECs as the in vitro model to evaluate the effect of QL. Firstly, our study demonstrated that QL increased oxLDL-treated HCAECs viability in a dose dependent manner. Then, our data showed that QL decreased ox-LDL-treated HCAECs apoptosis in a dose dependent manner. Moreover, caspase-3 activity has a key role in cell apoptosis. Our results showed that QL decreased ox-LDL-induced caspase-3 activity, which are in accordance with the data that QL protected HCAECs from ox-LDL induced cell apoptosis. Thus, our results suggested that QL protects ox-LDL-enhanced HCAECs apoptosis by reducing caspase- 3 activity.

It is well known that angiogenesis plays a critical role in the recovery of cardiac function in response to a number of injuries [22]. ECs are important for myocardial angiogenesis and directly affect with myocardium. The previous study suggested that QL reduced cardiac myocytes apoptosis. Our data implied QL maintained physiological function of ECs, characterized by enhanced migration and tube formation ability.

All the results implied that the apoptotic signaling might be essential for the protective effects of QL on ox-LDL-treated HCAECs. So QL may be used as a new therapeutic agent for atherosclerosis. Furthermore, molecular mechanisms should be investigated in vitro and in vivo models.

\section{Conflict of Interest}

The authors did not report any conflict of interest.

\section{References}

1. Zhang T, Tian F, Wang J, Jing J, Zhou SS, Chen YD. Atherosclerosis-associated endothelial cell apoptosis by MiR-429-mediated down regulation of Bcl-2. Cell Physiol Biochem 2015; 37: 1421-1430.

2. Chistiakov DA, Orekhov AN, Bobryshev YV. LOX-1Mediated Effects on Vascular Cells in Atherosclerosis. Cell Physiol Biochem 2016; 38: 1851-1859.

3. Prendergast C, Quayle J, Burdyga T, Wray S. Atherosclerosis differentially affects calcium signalling in endothelial cells from aortic arch and thoracic aorta in Apolipoprotein E knockout mice. Physiol Rep 2014; 2.

4. Petri MH, Laguna-Fernandez A, Gonzalez-Diez M, Paulsson-Berne G, Hansson GK, Back M. The role of the FPR2/ALX receptor in atherosclerosis development and plaque stability. Cardiovasc Res 2015; 105: 65-74.

5. Akhmedov A, Rozenberg I, Paneni F, Camici GG, Shi Y, Doerries C. Endothelial overexpression of LOX-1 increases plaque formation and promotes atherosclerosis in vivo. Eur Heart J 2014; 35: 2839-2848.

6. He D, Wang $\mathrm{H}, \mathrm{Xu} \mathrm{L}$, Wang $\mathrm{X}$, Peng $\mathrm{K}$, Wang $\mathrm{L}$. Saikosaponin-a attenuates oxidized LDL uptake and prompts cholesterol efflux in THP-1 cells. J Cardiovasc Pharmacol 2016.

7. Chen M, Masaki T, Sawamura T. LOX-1, the receptor for oxidized low-density lipoprotein identified from endothelial cells: implications in endothelial dysfunction and atherosclerosis. Pharmacol Ther 2002; 95: 89-100.

8. Chen J, Liu Y, Liu H, Hermonat PL, Mehta JL. Lectin-like oxidized low-density lipoprotein receptor-1 (LOX-1) transcriptional regulation by Oct-1 in human endothelial 
cells: implications for atherosclerosis. Biochem J 2006; 393: 255-265.

9. Zhang H, Li S, Zhou Q, Sun Q, Shen S, Zhou Y. Qiliqiangxin attenuates phenylephrine-induced cardiac hypertrophy through downregulation of MiR-199a-5p. Cell Physiol Biochem 2016; 38: 1743-1751.

10. Lin S, Wu X, Tao L, Bei Y, Zhang H, Zhou Y. The metabolic effects of traditional Chinese medication Qiliqiangxin on H9C2 cardiomyocytes. Cell Physiol Biochem 2015; 37: 2246-2256.

11. Wang X, He X, Hu S, Sun A, Lu C. Involvement of Bim in Photofrin-mediated photodynamically induced apoptosis. Cell Physiol Biochem 2015; 35: 1527-1536.

12. Surico D, Farruggio S, Marotta P, Raina G, Mary D, Surico N. Human chorionic gonadotropin protects vascular endothelial cells from oxidative stress by apoptosis inhibition, cell survival signalling activation and mitochondrial function protection. Cell Physiol Biochem 2015; 36: 2108-2120.

13. Ruan Y, Dong C, Patel J, Duan C, Wang X, Wu X. SIRT1 suppresses doxorubicin-induced cardiotoxicity by regulating the oxidative stress and p38MAPK pathways. Cell Physiol Biochem 2015; 35: 1116-1124.

14. Li Q, Wang Y, Li H, Shen G, Hu S. Ox-LDL influences peripheral Th17/Treg balance by modulating Treg apoptosis and Th17 proliferation in atherosclerotic cerebral infarction. Cell Physiol Biochem 2014; 33: 1849-1862.

15. Zhang BC, Zhang CW, Wang C, Pan DF, Xu TD, Li DY. Luteolin attenuates foam cell formation and apoptosis in Ox-LDL-stimulated macrophages by enhancing autophagy. Cell Physiol Biochem 2016; 39: 2065-2076.

16. Guo R, Su Y, Liu B, Li S, Zhou S, Xu Y. Resveratrol suppresses oxidised low-density lipoprotein-induced macrophage apoptosis through inhibition of intracellular reactive oxygen species generation, LOX-1, and the p38 MAPK pathway. Cell Physiol Biochem 2014; 34: 603-616.
17.Zhang X, Chen S, Wang Y. Honokiol up-regulates prostacyclin synthease protein expression and inhibits endothelial cell apoptosis. Eur J Pharmacol 2007; 554: 1-7.

18. Wu CY, Tang ZH, Jiang L, Li XF, Jiang ZS, Liu LS. PCSK9 siRNA inhibits HUVEC apoptosis induced by oxLDL via Bcl/Bax-caspase9-caspase3 pathway. Mol Cell Biochem 2012; 359: 347-358.

19. Cheng W, Yu P, Wang L, Shen C, Song X, Chen J. Sonic hedgehog signaling mediates resveratrol to increase proliferation of neural stem cells after oxygen-glucose deprivation/reoxygenation injury in vitro. Cell Physiol Biochem 2015; 35: 2019-2032.

20. Zhong ZY, Tang Y. Upregulation of periostin prevents high glucose-induced mitochondrial apoptosis in human umbilical vein endothelial cells via activation of $\mathrm{Nrf} 2 / \mathrm{HO}-1$ signaling. Cell Physiol Biochem 2016; 39: 71-80.

21. Birck MM, Saraste A, Hyttel P, Odermarsky M, Liuba P, Saukko P. Endothelial cell death and intimal foam cell accumulation in the coronary artery of infected hypercholesterolemic minipigs. J Cardiovasc Transl Res 2013; 6: 579-587.

22. Jin P, Li T, Li X, Shen X, Zhao Y. Suppression of oxidative stress in endothelial progenitor cells promotes angiogenesis and improves cardiac function following myocardial infarction in diabetic mice. Exp Ther Med 2016; 11: 2163-2170.

\section{${ }^{*}$ Correspondence to}

Haijun Cao

Department of Anesthesia

The Central Hospital of Tai'an

PR China 